Kalina Jastrzębowska

https://doi.org/10.26881/pwe.2021.52.13

ORCID: 0000-0002-0973-9501

University of Warsaw, Poland

kw.jastrzebows@student.uw.edu.pl

\title{
Opening tasks, opening minds - a rediscovery of the open-ended approach
}

\begin{abstract}
A child needs movement, air and light (...) a glance into the future, a feeling of freedom - an open window.
\end{abstract}

Korczak (1926: 24)

\begin{abstract}
Summary
Open-ended tasks are designed such that they may have more than one correct solution or may be solved in more than one way. Although such tasks constitute an irreplaceable tool for prompting young learners to be actively and creatively involved in mathematical discourse, their implementation poses a challenge. Primary school students in Poland are usually offered algorithmic and rote teaching methods and are thus very often deprived of important elements of successful mathematics learning. The ubiquitous teacher-centred approach dedicates little time to any contribution from learners. The aim of this design research was to implement a change in early childhood mathematics education. The change comprised students creating and/or solving open-ended tasks in groups, thus promoting dialogic teaching. The results confirmed that students who are challenged with openended tasks through dialogic teaching not only genuinely engage in their activities, develop a better number sense and flexibility of thinking, but also help each other gain a deeper understanding of new concepts. Captured in this research were the synergistic images of the beauty of children's reasoning and the beauty of mathematics as an open subject - an incentive for others to begin their journey with freedom of speech for young mathematicians.
\end{abstract}

Keywords: dialogic teaching, early childhood mathematics education, mathematical problem solving, open-ended approach, settings in dialogic classroom

Słowa kluczowe: nauczanie oparte na dialogu, wczesnoszkolne nauczanie matematyki, rozwiązywanie zadań problemowych, podejście otwarte w nauczaniu matematyki, warunki w klasie sprzyjające nawiązywaniu dialogu 


\section{Problems in need of addressing}

Many researchers in Poland have been drawing attention to the problematic issues that surround the quality of elementary school mathematics. Zbigniew Semadeni points out the need for replacing behaviourist pedagogy with the constructivist approach towards teaching. He states that the three fundamental aspects of a child's learning process should be:

- developing intuition of concepts in the child's mind based on experienced situations and actions taken by a child;

- promoting arithmetical skills related to these experiences;

- application of concepts and skills in everyday life situations that a child finds important (Semadeni 2015).

Providing cognitive conflicts can be helpful not only in evolving concepts but also in making sense of words and symbols.

According to the 2013 and 2015 findings of the Educational Research Institute (Instytut Badań Edukacyjnych, IBE), there are several problems accompanying early childhood mathematics education in Poland. A teacher's approach towards teaching/learning of the subject greatly influences students' conduct. The transposition of problems diagnosed on the teacher's end onto student performance is presented in the table below.

Table 1. Transposition of teacher-based problems onto student performance

\begin{tabular}{|l|l|}
\hline \multicolumn{1}{|c|}{ Teacher } & \multicolumn{1}{c|}{ Student } \\
\hline $\begin{array}{l}\text { Lack of subject knowledge; uncertainty in } \\
\text { accepting unusual solutions }\end{array}$ & Lack of opportunities to share interesting ideas \\
\hline Teacher-centred teaching & $\begin{array}{l}\text { Lack of communication; sense of self-agency } \\
\text { and sense of success missing }\end{array}$ \\
\hline Endorsement of one and only solution & Curiosity and creativity absent \\
\hline $\begin{array}{l}\text { Lack of developing and deepening problem- } \\
\text { solving skills and reasoning skills }\end{array}$ & $\begin{array}{l}\text { Creating passive cognitive attitude, aversion } \\
\text { and fear towards one's own search for answers }\end{array}$ \\
\hline Reluctance to orchestrate group work & Group work skills lacking \\
\hline $\begin{array}{l}\text { Treating homework as an empty ritual instead } \\
\text { of a tool to discover strengths/difficulties }\end{array}$ & Lack of motivation to act \\
\hline
\end{tabular}

Source: adapted by the author from Raport z badania. Szkoła samodzielnego myślenia (IBE 2013).

Serving verbal and procedural knowledge can only aid in replacing understanding with the mechanical use of schemes and rules (Szemińska 1981). Conscious acts of thinking are ousted by automatic execution of tasks.

An independent search for solutions can only take place if students are free from imposed knowledge of procedures. Offering freedom to young mathematicians is also promoted by other Polish researchers. They support the notion that children need time and space for their own mathematical activities without "helpful" adult interruptions (Gruszczyk-Kolczyńska 2009; Kalinowska 2010). 
Zbigniew Semadeni, Alina Kalinowska and Marek Dąbrowski all pay distinct attention to the importance of mathematical problem solving, especially to providing students with unconventional tasks (tasks with too much data, tasks with too little data or tasks with impossible data). Such tasks, which very rarely appear in regular textbooks, are usually reserved by teachers for a small group of "chosen students". These tasks can help children search for relationships between given values; they may convince pupils that school mathematics makes sense (Gruszczyk-Kolczyńska 2009); they also provide a chance to experience critical and creative thinking, which is not needed in solving typical tasks.

\section{Dialogic Teaching Framework Summation}

There are six main principles for dialogic teaching proposed and described by Robin Alexander:

- Collective - joint learning and enquiry;

- Reciprocal - listening to each other, sharing ideas, considering alternative viewpoints;

- Supportive - expressing ideas freely, no embarrassment or wrong answers, helping each other to reach common understanding;

- Cumulative - building on other people's contributions, forming coherent sequences of thinking and understanding;

- Deliberative - tackling problems from different angles, producing reasoned outcomes and resolutions;

- Purposeful - open and dialogic talk with specific learning goals in view (Alexander 2020: 131-133).

The role of the teacher in the dialogic classroom is to organize time, space and relationships in the direction of constant interactions, in which posing and answering challenging questions becomes a natural part of teaching and learning. Exchanges of thoughts deepen the understanding of concepts and help develop linguistic tools allowing for further thinking. Scaffolding and feedback are very important components of the process, helping in keeping up students' motivation, leading pupils to tackle problems with different perspectives. The liberating element on the teacher's part is "the professional mastery of the subject matter" (Alexander 2018: 571).

\section{Problem solving and open-ended approach}

As a process in which "previously acquired data are used in a new and unknown situation" (Kantowski 1980: 195), problem solving creates a foundation for mathematical studies. Many different skills are developed with pupils' exposure to problem solving practice. 
The above has been clearly formulated in the Mathematics Syllabus of the Ministry of Education in Singapore. Mathematical problem solving resonates in five areas of the learning process:

1. Attitudes: belief, appreciation, confidence, motivation, interest and perseverance;

2. Skills: proficiency in carrying out operations and algorithms, visualizing space, handling data and mathematical tools;

3. Concepts: understanding of properties and relationships, operations and algorithms;

4. Processes: competencies in abstracting and reasoning, representing and communicating, applying and modelling;

5. Metacognition: awareness, monitoring and regulation of thought processes (Singapore Ministry of Education 2021: 10).

Learning problem-solving strategies can start at the earliest stages of mathematics education. Elementary school students are able to discover various solutions to problems, they can ask questions, participate in analysing context-based situations, learn how to illustrate results by drawing tables or diagrams, formulate conjectures and attempt simple proofs.

Open-ended problems constitute a special group of mathematical problems. They were first developed in Japan in the 1970s and are now used in many countries as a tool to assess understanding, to introduce new topics and to use pupils' creative powers. "Tasks are said to be open if their starting and/or goal situation is not exactly given" (Pehkonen 1999: 57). The following examples of open-ended tasks can be offered to explain the definition thoroughly:

- Unknown starting situation: How many ways of expressing 100 can you find?

- Unknown goal situation: What numbers can you reach using all possible arithmetic operations and the numbers 3,9 and 20 ?

- Unknown starting and goal situation: How many children will you need to balance a house on a scale?

Open-ended problems allow for many different solutions or various strategies to be used in the solving process; they create natural grounds for differentiation, they encourage pupils' autonomy and active participation. The open-ended approach encourages persistence and independent thinking, invites modelling and application to the learning. It boosts mathematical language development, which supports thinking and reasoning. Using open-ended problems can help with discovering new concepts as well as with providing an opportunity to show deep understanding of knowledge and skills. "Students have rich experiences in the pleasure of discovery and receive the approval from fellow students" (Sawada 1997: 24).

Implementing an open-ended approach and encouraging students to solve problems in groups creates many opportunities for verbal exchanges between all members of a mathematizing community. At the same time, dialogic teaching introduces the idea of interactive settings, which refer to different characteristics of working groups:

- Whole class teaching;

- Group work (teacher-led);

- Group work (student-led);

- Individual (teacher-student);

- Individual (student pairs) (Alexander 2020: 139). 


\section{Qualitative research choice}

Three qualitative research strategies that can be characterized by the interventionist nature are experimental research, design research and action research. The last two are open, with little control of the situation or data: "the educational materials or ways of teaching are emergent and adjustable" (Bakker 2018: 10). The boundaries between these two strategies may not seemvery clear, so Arthur Bakker thoroughly discusses their commonalities and differences. Both design research and action research are open, interventionist, reflective and cyclic processes, in which the researcher can participate. In action research, the researcher can only be a participant, design is possible, and focus is placed on action and improvement of a situation. Meanwhile, in design research, the researcher can also be an observer, design is necessary and focus is placed rather on instructional theory and improved design (Bakker 2018: 15).

The concise definition of design research was given by Bell as "those enterprises that involve intentional design coupled to empirical research and theorizing about what takes place in the authentic contexts where the designed objects come to be used" (Bell 2004: 245). Design research focuses on combining theory with a practical approach. A researcher plans to test his/her ideas for school improvement, looking for answers to the following questions: Is it going to work? How and why does it work? Design research helps to understand learning ecology - a complex system of interactions bridging many different levels of school life. It can be described as a set of cooperating systems and consists of elements such as tasks for the students, class discourse, classroom norms, tools and materials or teacher's actions (Cobb et al. 2003).

Besides having a predictive and advisory nature, design research is described by the following five characteristics:

- its grounds are the development of theories about learning and the means that are designed to support learning;

- interventionist nature - design research tries to create a response to a problematic situation;

- prospective and reflective components - designed conjecture is confronted with actual learning observed by researchers;

- cyclic nature - iterative process is composed of creating a model of change, implementing the model and analysis of collected materials (unexpected variations are welcome);

- intentional transferability - even if the model is prepared for a specific school environment, it must be general enough to be transferred (Bakker 2018).

Denis Philips points out that emphasis shouldn't be placed on the last part of a research cycle alone - testing the hypothesis is important but creating an educational model for intervention is usually the result of an arduous process. The earlier stages of research are scientifically significant and consist of identifying problems, investigating the relevant theoretical knowledge and coming up with possible treatment ready to be tested (Philips 2006). 
Hans Reichenbach, cited by Philips, termed this preliminary effort "context of discovery", and stressed the importance of these phases of a cycle (Reichenbach 1938).

\section{Methodology}

This design research was carried out in an international private school following the PYP programme in Warsaw, Poland. It was the natural extension of a broader research process, which spanned three years of cycles of implementation of the British curriculum, growth mindset, dialogic teaching and, finally, an open-ended approach.

This research project was originally initiated as a result of high demand for a didactical intervention (curriculum improvement) due to requests from International Baccalaureate Organization (IBO) inspectors after their visitation to the school. The strong need for support in the development of mathematics education was also suggested by parents of the schoolchildren.

Problems that were diagnosed by the researcher upon joining the school environment confirmed the typical issues present in other Polish schools:

- a dearth of enthusiasm for the subject on the students' part;

- non-intuitive teaching practices;

- insufficient confidence in subject knowledge on the teachers' part;

- educational models lacking in inspiration for pupils and teachers to start building a common understanding of the value and beauty of mathematics.

In the methodological framework of design research, the implementation of an openended approach began to transform classroom culture by activating students' creative abilities applied to problem solving and construction of tasks.

\section{Conjecture mapping}

One of the possible ways to visualize design research design is by conjecture mapping. This illustrates how a general idea (a high-level conjecture) is going to foster particular types of learning or achieve various educational goals. Conjecture mapping also consists of embodiment that leads to mediating processes. These processes are hypothesized to lead to specific outcomes of the project. The map also illustrates two types of conjectures that can be empirically tested:

- Design conjectures: "If learners engage in this activity (task + participant) structure with these tools, through discursive practice, then this mediating process will emerge" (Sandoval 2014: 24);

- Theoretical conjectures: "If this mediating process occurs it will lead to this outcome" (Sandoval 2014: 24).

The figure below presents the conjecture map constructed for this design research, inspired by the generalized form proposed by Sandoval (2014: 21): 


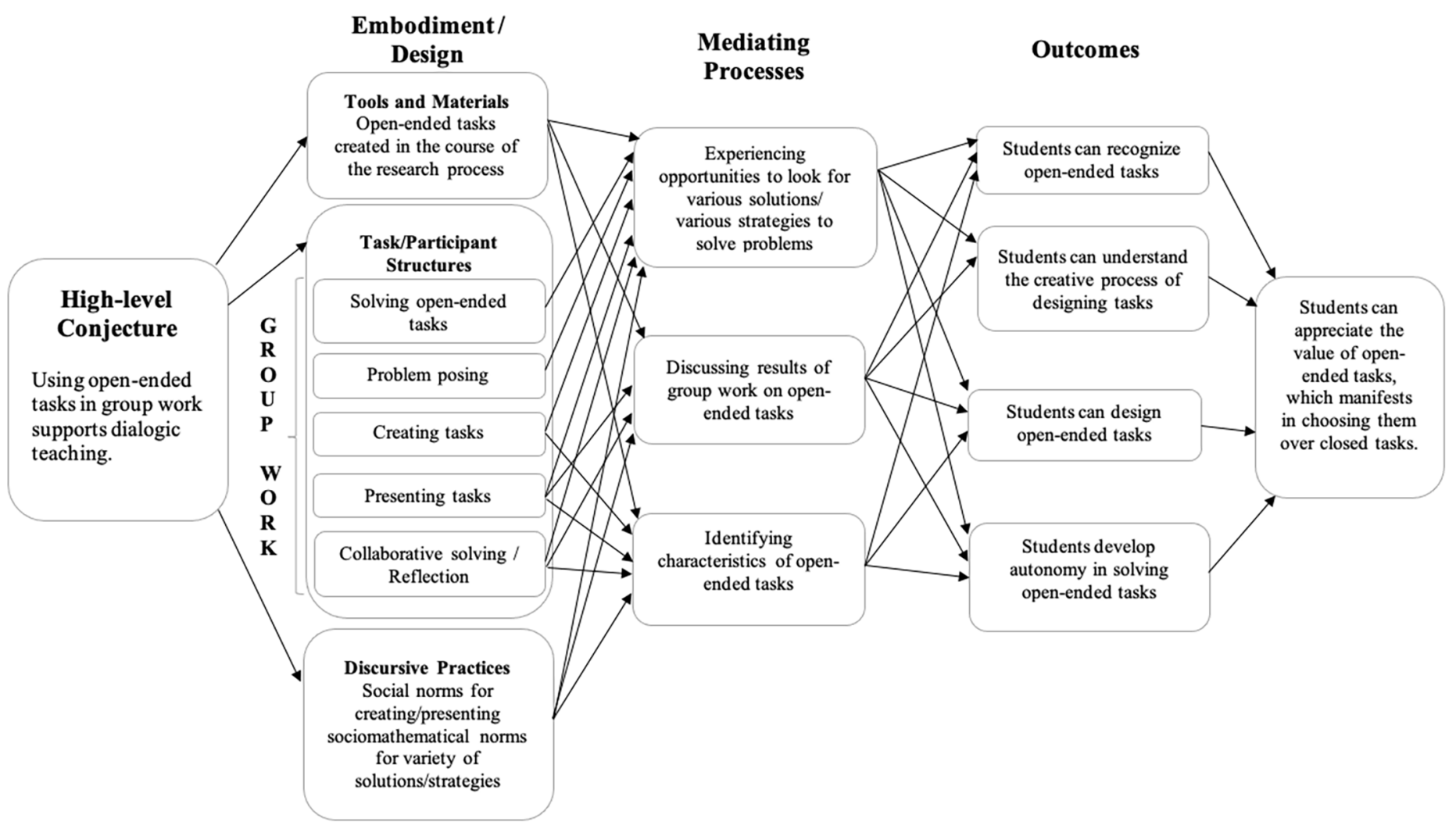

Figure 1. Conjecture map constructed by the author for this research ( 2 years into the project)

Source: adapted by the author from Sandoval (2014: 21). 
Research aim: Implementing change in early childhood mathematics education (Year 1 to 4 ) and providing insight into how this could be and was done: creating and/or solving open-ended tasks in groups by the students.

Hypothesis: Dialogic teaching can be promoted by implementing open-ended approach and group work. The designed change will help develop communication in the classroom by affecting classroom norms regarding mathematical discourse.

Research question: How can open-ended approach and group work support dialogic teaching?

Research methods: Lesson observations/participation, data analysis (field notes, students' work samples, discussions with teachers-observers and students).

Description of the research process: The role of the teacher-researcher was to orchestrate activities and to reflect on students' performance, building on the natural synergy between innovative curriculum improvement and teacher development, and providing insight into how this could be and was done. Seven classes were taught and observed by the researcher, five lessons per week for each class within the course of two school years: 2018/2019 and 2019/2020. Class sizes and girl: boy ratios for each school year are presented in the table below.

Table 2. Girl: boy ratio in grades partaking in action research

\begin{tabular}{|l|c|c|l|c|c|}
\hline \multicolumn{3}{|c|}{ 2018/2019 School Year } & \multicolumn{2}{c|}{ 2019/2020 School Year } \\
\hline class grade & girls & boys & class grade & girls & boys \\
\hline Two Year 1 & 11 & 14 & Two Year 1 & 11 & 15 \\
\hline One Year 2 & 8 & 9 & Two Year 2 & 12 & 11 \\
\hline Two Year 3 & 6 & 15 & One Year 3 & 6 & 7 \\
\hline Two Year 4 & 8 & 23 & Two Year 4 & 12 & 12 \\
\hline
\end{tabular}

Source: own research.

Cycles of action and reflection, theory and practice, as well as transformational reciprocity in the pursuit of developing a flourishing community of inquirers engaged in solving and designing their own mathematical tasks, became a part of the participatory research process.

\section{Results: Examples of student work}

Throughout the duration of the research process, the students were equipped with inquirybased learning opportunities during mathematics lessons. The following are examples of tasks and students' solutions from these lessons. They have been categorized according to the interactive setting chosen for the solving process. 
The first set of problems consists of tasks that were solved in the whole class teaching setting. They are presented in the photographs below (Samples of classwork 1 through 4).

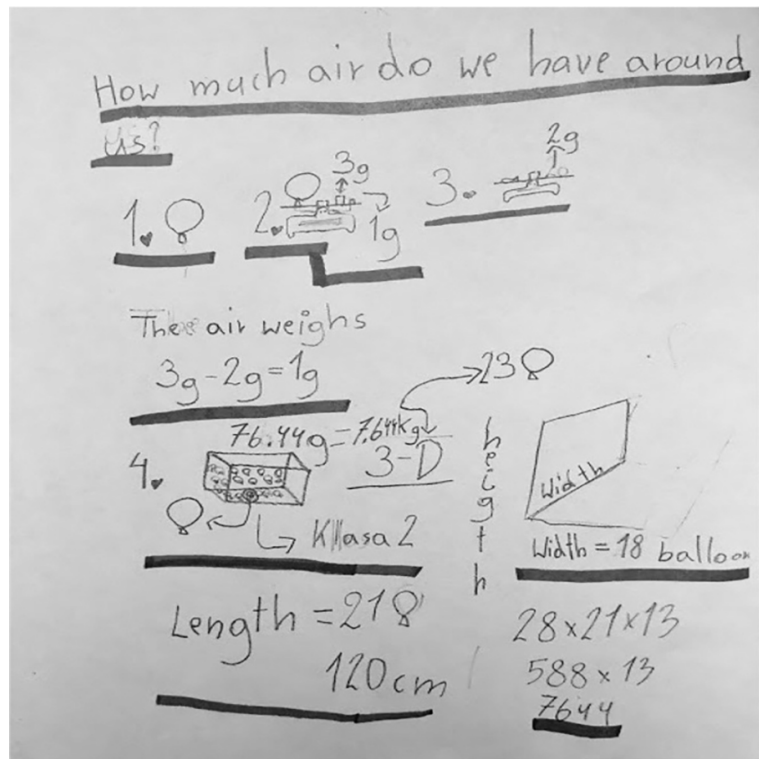

Sample of classwork 1. Teacher-led whole class teaching, Year 2: How much air do we have around us?

Source: the author's research archives.

This task brought the students together to figure out how to weigh the air trapped in a balloon, and then to estimate how many balloons could fit in the classroom.

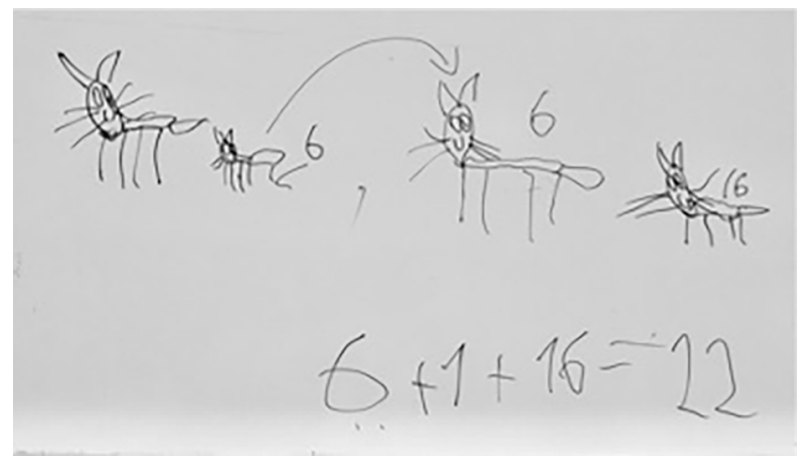

Sample of classwork 2. Student-led whole class teaching / problem posing, Year 1: A cat gave birth to 6 kittens and they grew up... How many cats are there?

Source: the author's research archives. 
Despite there being a mistake in the addition total, the effort made by the pupil to conceal part of the data offered is worth noting ( 6 cats that grew could be counted twice by an inattentive classmate).
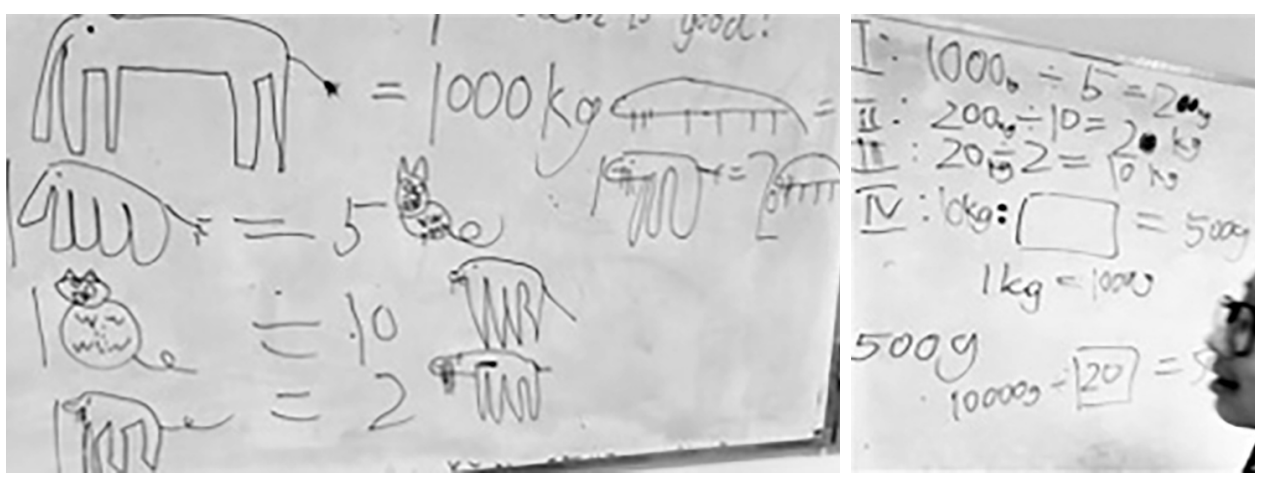

Sample of classwork 3 and 4. Student-led whole class teaching / problem posing, Year 4: I know some relationships between animals' weights. How much does each animal weigh?

Source: the author's research archives.

These two examples (Sample 2, 3 and 4) can give a glimpse into the sophisticated mind of a child as a mathematical problem designer. Witnessing the process of creating such tasks becomes a real treat in a classroom in which students are offered freedom to express themselves.

Teacher-led whole class teaching / problem posing, Year 2, 3 and 4: Which solution is better for the planet - buying 1 big bottle of laundry detergent or buying 3 small ones?

- Year 2 answer: We need to weigh 1 bottle and 3 little ones and compare the results.

- Year 3 answer: Let's melt 1 big bottle and 3 little ones and check where we'll have more plastic.

- Year 4 answer: Let's cover these bottles with little square paper pieces, measure the thickness of both bottle types and calculate their volume.

Students at different levels tried different approaches to solve this problem; this corresponded with their creativity and/or subject knowledge. They discussed the given problem in groups and then each group presented their conclusions. Only a few examples of students' answers are cited above.

The next set of tasks refers to group work activities. They are presented in the photographs below (Samples of classwork 5 through 9). 


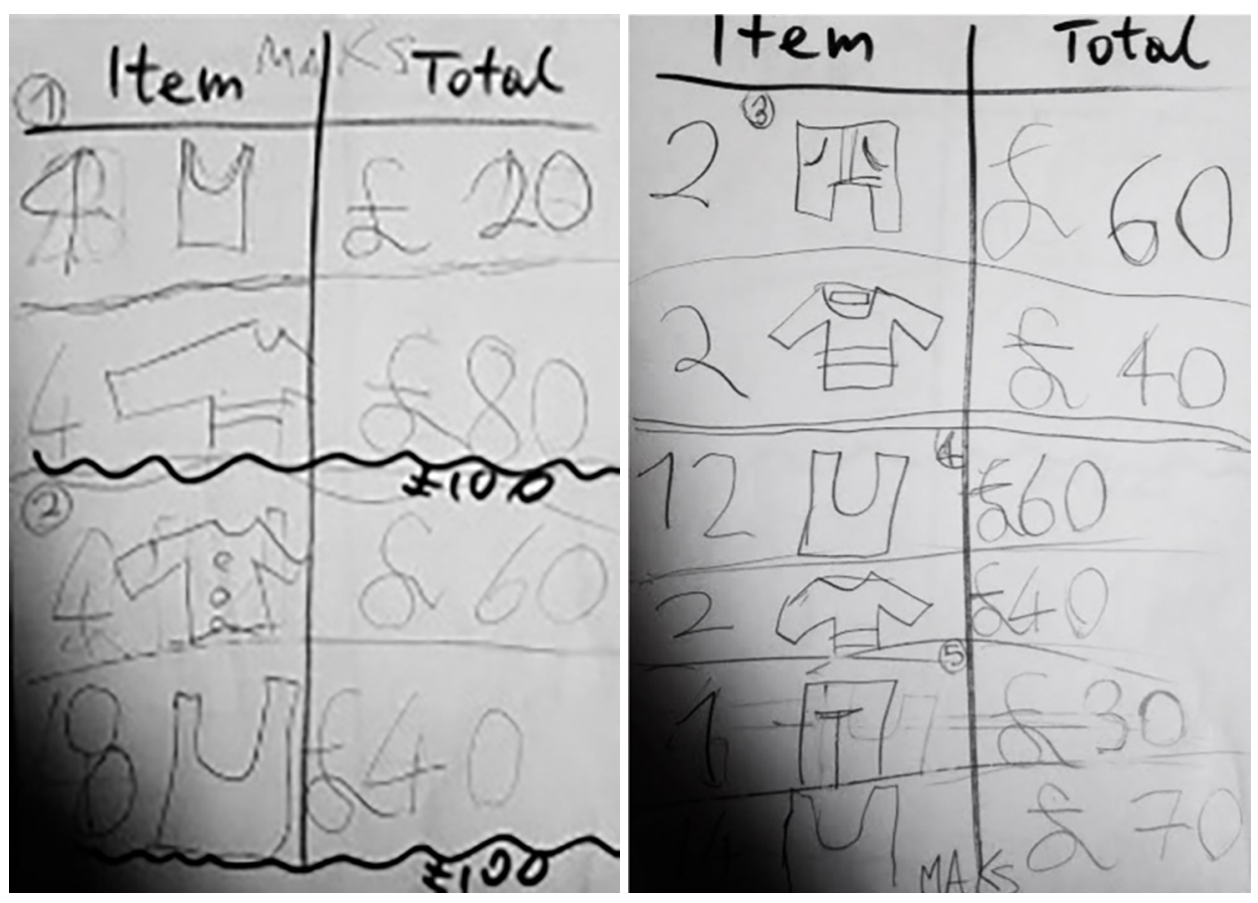

Sample of classwork 5 and 6. Student-led group work, Year 1: Find as many combinations of items as possible to spend $£ 100$

Source: the author's research archives.

Students had a chance to present their choices to the whole class.

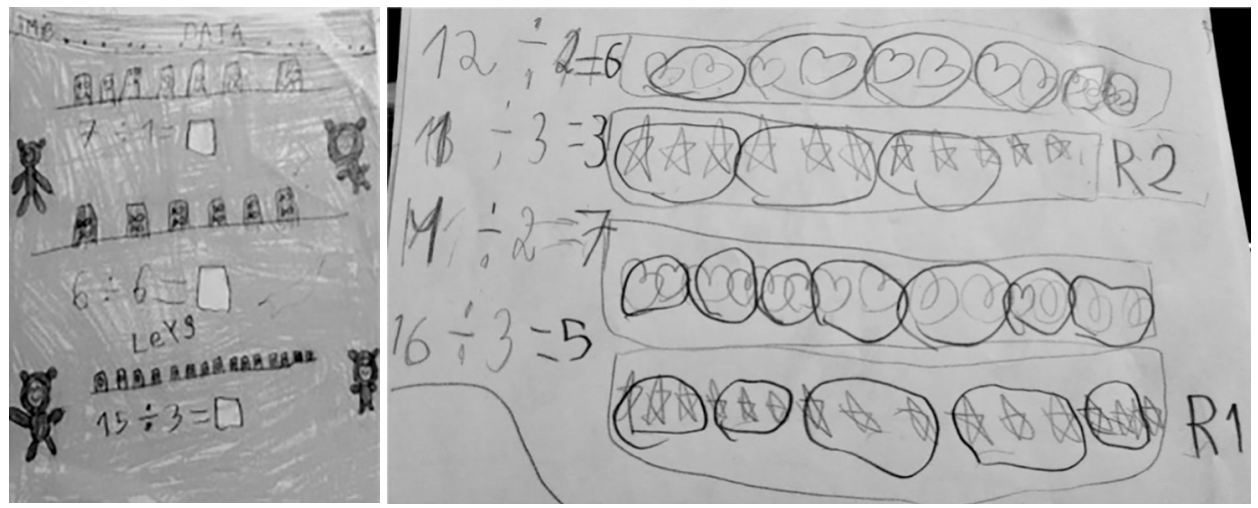

Sample of classwork 7 and 8. Teacher-student, individual, Year 1: Designing division tasks for other students

Source: the author's research archives. 
Some students took time to beautify their work, knowing that copies would be made for others to enjoy and complete their self-designed task. The discovery of division with a remainder took place during this process.

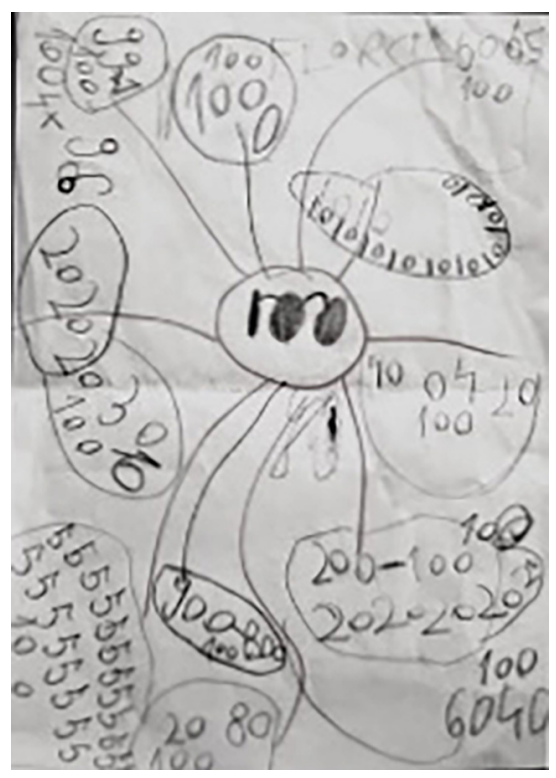

Sample of classwork 9. Student pairs, individual, Year 1: Making 100

Source: the author's research archives.

Students in Year 1 will use any opportunity to make a masterpiece!

\section{Conclusions - Part I}

In order for the implementation to prove successful, certain aspects of the learning ecology needed to be renegotiated, as presented below.

Students' role in the learning process:

- To ask questions if there is a need for better understanding;

- To know what everybody in the group is responsible for (different roles assigned to group members) - gaining social autonomy;

- To make sure that each group member is able to explain the findings before the whole-class discussion starts - gaining intellectual autonomy;

- To provide justification to his/her thinking;

- To compare findings with those prepared by the other group (sometimes checking the results or explaining reasons for making mistakes) - gaining agency. 
Teacher's role in the learning process:

- To create opportunities for every class member to think and reason;

- To ask "good questions";

- To invite new ideas;

- To build from or to extend students' ideas;

- To help children understand the role of "good mistakes";

- To highlight solution methods;

- To be open to different strategies for solving tasks;

- To listen to the students and try to make sense of what they have to say, sometimes to serve as a translator by paraphrasing unclear explanations and by using proper mathematical language (scaffolding).

\section{Conclusions - Part II}

Broadening the collection of tools and materials (e.g. open-ended task sets for Year 1-4 students) was followed by gathering evidence and insight into how the process of changes was developing. Again, these have been presented in two sets - in students' and teachers' dimensions.

\section{Students' dimension:}

- Collaborative reasoning turns many students into independent learners;

- By fostering pupils' creativity, an enthusiastic approach towards mathematical efforts is gained;

- Respect for all responses builds more confidence in individual learners - from beginners to advanced;

- Concept understanding and language development flourish as a result of constant verbal exchange (introduction and assessment of concepts);

- The relationship between the subject teacher and the student changes, becoming more open and personal, which translates into engagement in the subject;

- With grade advancement, students seem to have fewer and fewer creative powers (Is this a consequence of participation in the overall instruction-based environment?);

- Some students seem to feel lost when offered freedom to act.

\section{Teachers' dimension:}

- Difficult beginnings, hesitation on the teacher-observers' part, especially among those who are rather careful with exposing pupils to struggle zone challenges and also those who do not feel comfortable with problem solving - overeagerness to assist in the process (although help was meant to simplify the task, instead it constituted the replacement of task-solving with offering an algorithm, which sometimes 
was an algebraic formula (sic!); often full explanations were given, leaving no room for students' thinking and discovering);

- Teachers-observers sometimes perceived the dialogic classroom as chaotic;

- Problems with subject matter - area in need of strong support during university training as well as during professional development sessions for elementary school teachers;

- Improved communication and easier issue solving (between teacher-observers and teacher-researcher) after the first semester of teaching;

- The importance of paying special attention to inter-subject relationships in the teaching curriculum, real-life situations and time spent on final discussions after group work sessions (on the teacher-researcher's part).

A serious concern to address is the reform of the elementary teacher training structure. Problem-posing and problem-solving should become a part of the daily routine in mathematics education courses for future teachers. Without proper training one cannot expect young teachers to step down from easily trodden paths of algorithmic teaching.

To make it possible for teachers to accept an open-ended approach in elementary mathematics education, the whole system of beliefs on teaching and learning has to evolve. The role of a teacher as a knowledge feeder has to be replaced by the idea of a teacher as a guide and a constructor of learning situations.

There is also a need for change in the elementary school curriculum. More attention should be paid to problem solving, designing tasks, presenting them and then orchestrating a process of whole class solving led by students. The openness and beauty of mathematics cannot be emphasized more than by offering children freedom to act and create.

\section{References}

Alexander R.J. (2018), Developing dialogic teaching: genesis, process, trial. "Research Papers in Education", 33(5).

Alexander R.J. (2020), A Dialogic Teaching Companion. New York, Routledge.

Bakker A. (2018), Design Research in Education: A Practical Guide for Early Career Researchers. New York, Routledge.

Cobb P., Confrey J., diSessa A., Lehrer R., Schauble L. (2003), Design experiments in educational research. "Educational Researcher", 32(1).

Dąbrowski M. (2013), (Za)trudne, bo trzeba myśleć? O efektach nauczania matematyki na I etapie ksztatcenia. Warszawa, IBE.

Gruszczyk-Kolczyńska E. (2009), Wspomaganie rozwoju umysłowego oraz edukacja matematyczna dzieci w ostatnim roku wychowania przedszkolnego i w pierwszym roku szkolnej edukacji. Warszawa, Wydawnictwo Edukacja Polska.

IBE (2013), Raport z badania. Szkoła samodzielnego myślenia. Warszawa, IBE.

IBE (2015), Wnioski z badań i dyskusji dotyczace nauczania matematyki. Warszawa, IBE.

Kalinowska A. (2010), Pozwólmy dzieciom działać. Warszawa, Centralna Komisja Egzaminacyjna. 
Kantowski M.G. (1980), Some Thoughts on Teaching for Problems Solving. In: NCTM Yearbook 1980. Reston, National Council of Teachers of Mathematics.

Korczak J. (1926), Otwarte okno. „Szkoła Specjalna”, 3(1).

Pehkonen E. (ed.) (1997), Use of open-ended problems in mathematics classroom. Research Report 176. Helsinki, University of Helsinki, Department of Teacher Education.

Pehkonen E. (1999). Open-ended problems: A method for an educational change. In: M. Hejny, J. Novotna (eds.), Proceedings of International Symposium on Elementary Maths Teaching. Prague, Charles University, SEMT 99.

Philips D.C. (2006), Assessing the quality of design research proposals. In: J. Van den Akker, K.P.E. Gravemeijer, S. Mckenney, N. Nieveen (eds.), Educational design research. London, Routledge.

Reichenbach H. (1938), Experience and prediction. Chicago, University of Chicago Press.

Sandoval W. (2014), Conjecture Mapping: An Approach to Systematic Educational Design Research. "Journal of the Learning Sciences", 23(1).

Sawada T. (1997), Developing Lesson Plans. In: J. Becker, S. Shimada (eds.), The Open-Ended Approach: A New Proposal for Teaching Mathematics. Reston, National Council of Teachers of Mathematics.

Semadeni Z. (2015), Matematyka w edukacji początkowej - podejście konstruktywistyczne. In: Z. Semadeni, E. Gruszczyk-Kolczyńska, G. Treliński, B. Bugajska-Jaszczołt, M. Czajkowska, Matematyczna edukacja wczesnoszkolna. Teoria i praktyka. Kielce, Wydawnictwo Pedagogiczne ZNP.

Singapore Ministry of Education's Curriculum Planning and Development Division (2020), Primary School Subjects and Syllabuses. 2021 Mathematics Syllabus, Primary One to Six. Singapore, Ministry of Education.

Szemińska A. (1981), Rozwój pojęć matematycznych u dziecka. In: Z. Semadeni, Nauczanie początkowe matematyki. T. 1. Warszawa, Wydawnictwo Szkolne i Pedagogiczne. 